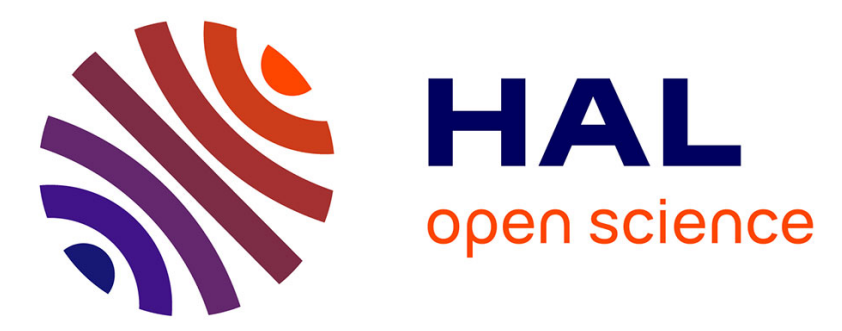

\title{
Dynamic modeling of MicroGrids
}

Georges Kariniotakis, N.L. Soultanis, A.I. Tsouchnikas, S.A. Papathanasiou, Nikos D. Hatziargyriou, Joao A. Pecas Lopes, N. Jayawarna, N. Jenkins

\section{To cite this version:}

Georges Kariniotakis, N.L. Soultanis, A.I. Tsouchnikas, S.A. Papathanasiou, Nikos D. Hatziargyriou, et al.. Dynamic modeling of MicroGrids. International Journal of Distributed Energy Resources, 2006, 2 (4), pp.279-303. hal-00526378

\section{HAL Id: hal-00526378 \\ https: / hal-mines-paristech.archives-ouvertes.fr/hal-00526378}

Submitted on 13 Jun 2018

HAL is a multi-disciplinary open access archive for the deposit and dissemination of scientific research documents, whether they are published or not. The documents may come from teaching and research institutions in France or abroad, or from public or private research centers.
L'archive ouverte pluridisciplinaire HAL, est destinée au dépôt et à la diffusion de documents scientifiques de niveau recherche, publiés ou non, émanant des établissements d'enseignement et de recherche français ou étrangers, des laboratoires publics ou privés. 


\title{
DYNAMIC MODELLING OF MICROGRIDS
}

\author{
G. N. Kariniotakis, \\ Ecole des Mines de Paris, Center for Energy and Processes, \\ B.P. No 207, 06904, Sophia-Antipolis Cedex \\ E-Mail: georges.kariniotakis@ensmp.fr \\ N. L. Soultanis, A. I. Tsouchnikas, \\ S. A. Papathanasiou, N. D. Hatziargyriou, \\ National Technical University of Athens, 15780 Athens, Greece \\ J. A. Peças Lopes, \\ INESC Porto, University of Porto, Portugal \\ N. Jayawarna, N. Jenkins \\ University of Manchester, UK
}

Keywords: microgrids; wind turbines; fuel cells; photovoltaic systems; microturbines; transient stability

\begin{abstract}
The interconnection of small, modular generation and storage technologies at the MV and LV distribution level have the potential to significantly impact power system performance. In this paper models of the main micro-generation sources are described. In particular, the models of Microturbines, Fuel Cells, Photovoltaic Systems and Wind Turbines, are described. In addition basic models of their power electronic interfaces are given. The above models have been integrated in a simulation platform able to represent the steady state and dynamic behavior of three phase networks. The simulation tool, which is developed in the framework of the EU funded MICROGRIDS project, is used to define and evaluate operational and control strategies for the microgrid paradigm.
\end{abstract}

International Journal of Distributed Energy Resources, ISSN 1614-7138, Volume 2 Number 4 (C) 2006 Technology \& Science Publishers, Kassel, Germany, http://www.ts-publishers.com 


\section{INTRODUCTION}

Small, modular generation technologies interconnected to low-voltage (LV) distribution systems have the potential to form a new type of power system, the MicroGrid [1], [2]. MicroGrids can be connected to the main power network or be operated autonomously, if they are operated from the power grid, in a similar manner to the power systems of physical islands. The micro-generators are small units of less than $100 \mathrm{kWs}$, most of them with power electronic interface, using either Renewable Energy Sources or fossil fuel in high efficiency local co-generation mode. Both of these technologies are critical to reducing GHG emissions and dependence on imported fossil fuel, where the MicroGrid concept will allow their most effective implementation.

MicroGrids may use single-phase circuits and be loaded with single-phase loads. These factors generate unbalanced conditions that can be accentuated with the interaction of dynamic loads such as induction motors. To model these effects, analysis tools must model the system with its three phases, the neutral conductors, the ground conductors and the connections to ground. Such tools should include steady state and dynamic models for the various forms of micro-sources and their interfaces.

This paper presents microsources models as well as the simulation platform developed in the frame of the MICROGRIDS project [1]. The platform is able to simulate the steady state and dynamic operation of LV three-phase networks that include micro generation. This involves the development of adequate models in the time range of ms of the micro sources, machines (induction and synchronous machines) and inverters. Normally these devices are directly coupled to the grid and thus have a direct impact on the grid voltage and frequency.

The paper presents the models used for symmetrical three phase and single phase induction generators, microturbines, fuel cell, wind turbines and grid side inverter. These are given as an example of modelling of microsources. Further models like models for photovoltaic systems and others are integrated in the simulation platform. These models are presented in detail in [8].

The analytical simulation tool is capable of representing the dynamic behaviour of micro-grids during grid-connected and autonomous operation, both in balanced and unbalanced conditions. The whole tool is built in Matlab and Simulink. The frequency domain representation (phasor approach) has been adopted to increase the simulation efficiency. Natural phase quantities $(a-b-c)$ are used, with proper treatment of neutral conductors. 


\section{MICROSOURCES MODELLING}

\section{A Three-Phase Symmetrical Induction Generator}

Induction machines are represented by the fourth order model expressed in the arbitrary reference frame. Using generator convention for the stator currents [9], [10]:

$$
\begin{gathered}
u_{s d}=-r_{s} \cdot i_{s d}-\omega \cdot \Psi_{s q}+p \Psi_{s d} \\
u_{s q}=-r_{s} \cdot i_{s q}+\omega \cdot \Psi_{s d}+p \Psi_{s q} \\
u_{r d}=r_{r} \cdot i_{r d}-\left(\omega-\omega_{r}\right) \cdot \Psi_{r q}+p \Psi_{r d} \\
u_{r q}=r_{r} \cdot i_{r q}+\left(\omega-\omega_{r}\right) \cdot \Psi_{r d}+p \Psi_{r q} \\
p=\frac{1}{\omega_{o}} \frac{d}{d t}, \quad \omega_{o}
\end{gathered}
$$

is the base cyclic frequency, $\omega$ is the rotating speed of the arbitrary reference frame and subscripts $\{d\},\{q\},\{s\},\{r\}$ denote $d q$-axis, stator, rotor, respectively.

The fluxes are related to the stator, rotor winding currents by the following equations

$$
\begin{aligned}
& \Psi_{s d}=-X_{s} \cdot i_{s d}+X_{m} \cdot i_{r d} \\
& \Psi_{s q}=-X_{s} \cdot i_{s q}+X_{m} \cdot i_{r q} \\
& \Psi_{r d}=-X_{m} \cdot i_{s d}+X_{r} \cdot i_{r d} \\
& \Psi_{r q}=-X_{m} \cdot i_{s q}+X_{r} \cdot i_{r q}
\end{aligned}
$$

The electromagnetic torque is given by:

$$
T_{e}=\Psi_{q r} \cdot i_{d r}-\Psi_{d r} \cdot i_{q r}
$$

\section{B Single-Phase Induction Generator}

The dynamic model of a single-phase induction machine in the stator reference frame is described next. All quantities are referred to the main winding (denoted by the use of double prime).

$$
v_{q s}=R_{1 m} \cdot i_{q s}+p \Psi_{q s}
$$

International Journal of Distributed Energy Resources, ISSN 1614-7138, Volume 2 Number 4 (c) 2006 Technology \& Science Publishers, Kassel, Germany, http://www.ts-publishers.com 


$$
\begin{aligned}
& v_{q r}^{\prime}=R_{2 m} \cdot i_{q r}^{\prime}-\omega_{r} \cdot \Psi_{d r}^{\prime \prime}+p \Psi_{q r}^{\prime} \\
& v_{d r}^{\prime \prime}=R_{2 m} \cdot i_{d r}^{\prime \prime}+\omega_{r} \cdot \Psi_{q r}^{\prime}+p \Psi_{d r}^{\prime \prime} \\
& \Psi_{q s}=X_{1 m} \cdot i_{q s}+X_{M m}\left(i_{q s}+i_{q r}^{\prime}\right) \\
& \Psi_{q r}^{\prime}=X_{2 m} \cdot i_{q r}^{\prime}+X_{M m}\left(i_{q s}+i_{q r}^{\prime}\right) \\
& \Psi_{d r}^{\prime \prime}=\left(X_{2 m}+X_{M m}\right) i_{d r}^{\prime \prime} \\
& i_{d r}^{\prime \prime}=\frac{N_{a}}{N_{m}} i_{d r}^{\prime}
\end{aligned}
$$

Subscript $\{m\}$ denotes $m$ winding. The electromagnetic torque is given by:

$$
T_{e}=\frac{P}{2}\left(\lambda_{q r}^{\prime} \cdot i_{d r}^{\prime \prime}-\lambda_{d r}^{\prime \prime} \cdot i_{q r}^{\prime}\right)
$$

\section{Microturbines}

Microturbines are small and simple-cycle gas turbines with outputs ranging typically from around 25 to $300 \mathrm{~kW}$. They are part of a general evolution in gas turbine technology. Techniques incorporated into the larger machines, to improve performance, can be typically found in microturbines as well. These include recuperation, low $N O_{X}$ emission technologies, and the use of advanced materials, such as ceramics, for the hot section parts [10].

There are essentially two types of microturbines. One is a high-speed single-shaft unit with a compressor and turbine mounted on the same shaft as an electrical synchronous machine. In this case turbine speeds mainly range from 50.000 to $120.000 \mathrm{rpm}$. The other type of microturbines is a split-shaft designed one that uses a power turbine rotating at $3000 \mathrm{rpm}$ and a conventional generator connected via a gearbox. In typical microturbine designs, this micro-generation system is composed of the following main parts:

Turbine and Recuperator: The primary machine is a small gas turbine. The recuperator is a heat exchanger, which transfers heat from the exhaust gas to the discharge air before it enters the combustor. This reduces the amount of fuel required to raise the discharge air temperature to that required by the turbine.

Electrical generator: In the single-shaft design, a synchronous generator is directly coupled to the single shaft turbine. The rotor is either a two- or four-pole permanent magnet with a stator that presents a conventional copper wound design. In the split-shaft design, a conventional induction or synchronous machine is mounted on the power turbine via a gearbox.

International Journal of Distributed Energy Resources, ISSN 1614-7138, Volume 2 Number 4 (c) 2006 Technology \& Science Publishers, Kassel, Germany, http://www.ts-publishers.com 
Power electronics: In the single-shaft design, the alternator generates a very high frequency three- phase voltage ranging from 1500 to $4000 \mathrm{~Hz}$. To allow grid interconnection, the high frequency voltage needs to be first rectified and then inverted to a normal $50 \mathrm{~Hz}$ voltage. In the split-shaft turbine design, power inverters are not needed since the generator is directly coupled to the grid.

Since in this research we are mainly interested in the dynamic performance of the network and not the fast transients that may happen, the microturbine model adopted is based on the following assumptions:

1. The recuperator is not included in the model since it is mainly used to raise engine efficiency.

2. The gas turbine's temperature control and the acceleration control have no impact in normal operating conditions. Therefore they can be omitted in the turbine model.

A simplified block diagram for the microturbine for load following dynamic behavior analysis purposes is shown in Fig. 1. The details of these control blocks with all parameters are given next.

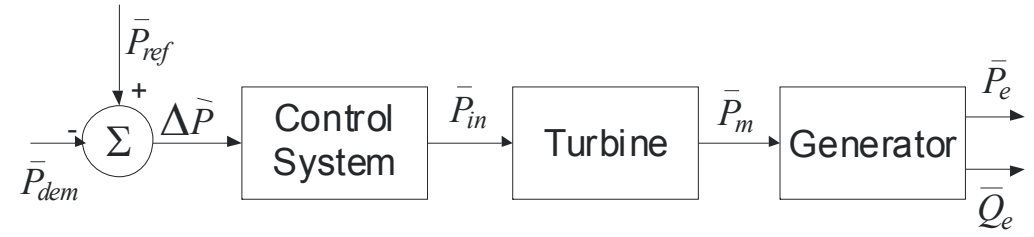

Figure 1a: Main blocks in microturbine model

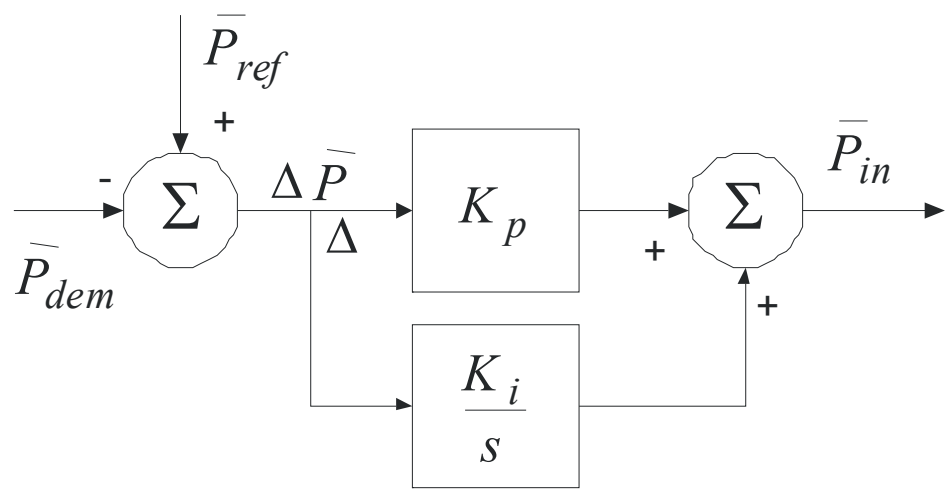

Figure 2b: Load following control system model

The real power control can be described as a proportional-integral (PI) control function as shown in the lower diagram of Figure 2. The real power control variable Pin is then applied to the turbine. Pdem is the demanded power, Pref is the reference power, Pin is the power control variable to be applied to the turbine, Kp

International Journal of Distributed Energy Resources, ISSN 1614-7138, Volume 2 Number 4

(c) 2006 Technology \& Science Publishers, Kassel, Germany, http://www.ts-publishers.com 
is the proportional gain and $\mathrm{Ki}$ is the integral gain in the PI controller. Detailed equations on PI controllers are found in [4], [12].

The GAST turbine model is one of the most commonly used dynamic models of gas turbine units [13]. The model is simple and follows typical modelling guidelines [14]. Therefore the turbine part in this microturbine design is modelled as GAST model.

In Fig. 3, Pm is the mechanical power, Dtur is the damping of turbine, T1 is the fuel system lag time constant 1, T2 is the fuel system lag time constant 2, T3 is the load limit time constant, Lmax is the load limit, Vmax is the maximum value position, Vmin is the minimum value position, $\mathrm{KT}$ is the temperature control loop gain.

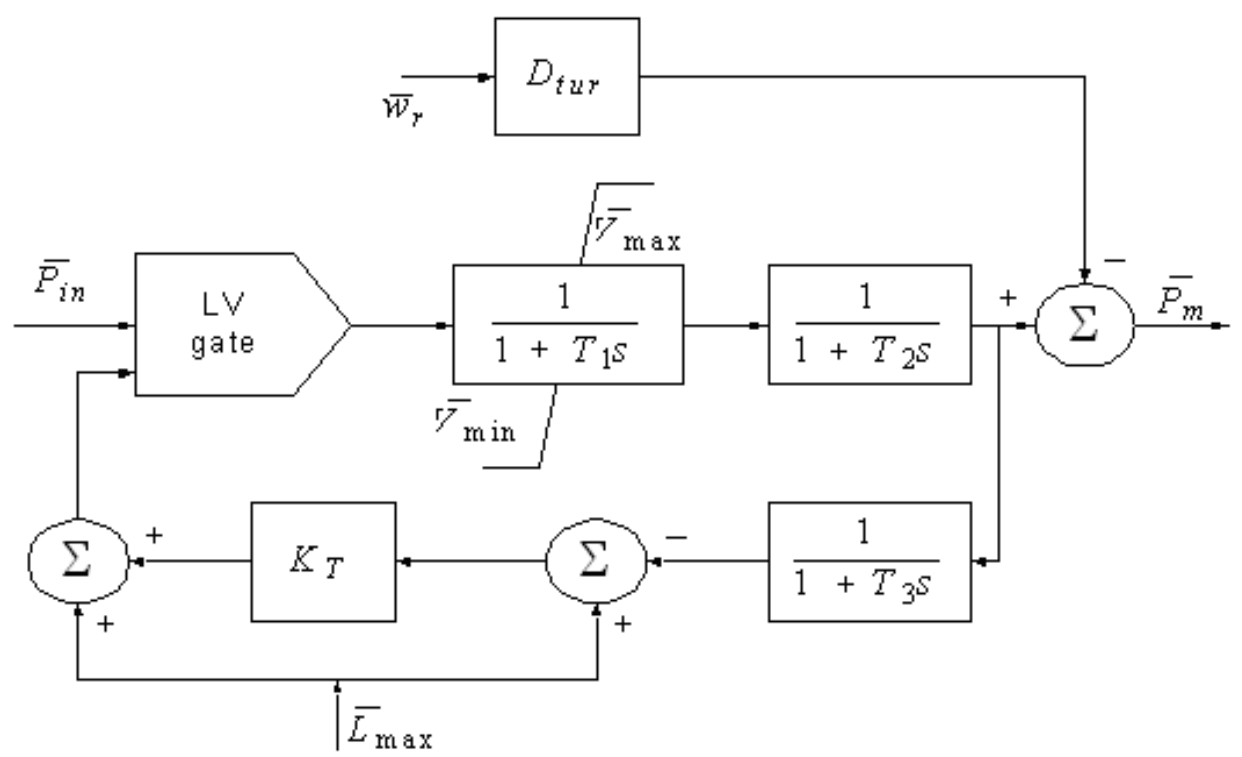

Fig. 3: $\quad$ Turbine model

In the microturbines that are designed to operate in stand alone conditions a battery is connected to the dc link to help providing fast response to load increases. The interface with the grid is also provided by an inverter.

\section{Fuel Cells}

Nowadays there are available five different types of fuel cells:

- $A F C$ - Alcaline Fuel Cell;

- $\quad P E F C / P E M-P o l y m e r$ Electrolyte Fuel Cell/Proton Exchange Membrane;

- $\quad P A F C$ - Phosphoric Acid Fuel Cell;

- $M C F C$ - Molten Carbonate Fuel Cell;

- $\quad S O F C$ - Solid Oxid Fuel Cell. 
The Solid Oxide Fuel Cell (SOFC) technology offers higher efficiencies and provides a great amount of heat (with high operating temperature - between 600 and $1000{ }^{\circ} \mathrm{C}$ ) turning into an interesting technology for cogeneration and more specifically residential-building scale distributed generation. The SOFC model is described in this paper. A power generation fuel cell system has the following three main parts:

Fuel processor The fuel processor converts fuels such as natural gas to hydrogen and by product gases.

Power section The power section generates the electricity. There are numerous individual electrochemical fuel cells in the power section.

Power conditioner The power conditioner converts $d c$ power to ac power output and includes current, voltage and frequency control.

\section{Fuel Cell Modeling}

It is assumed that the anode is supplied with $H_{2}$ only and the cathode with $\mathrm{O}_{2}$ only, so that the only reaction that occurs in the fuel cell is:

$$
\mathrm{H}_{2}+\frac{1}{2} \mathrm{O}_{2} \rightarrow \mathrm{H}_{2} \mathrm{O}
$$

The potential difference between the anode and the cathode is calculated using the Nernst's equation and Ohm's law:

$$
V_{f c}^{r}=N_{0} \cdot\left[E_{0}+\frac{R \cdot T}{2 F}\left(\ln \frac{p_{\mathrm{H}_{2} \mathrm{O}} \cdot p_{\mathrm{O}_{2}}^{1 / 2}}{p_{\mathrm{H}_{2} \mathrm{O}}}\right)\right]-r \cdot I_{f c}^{r}
$$

where, $E_{0}$ is the voltage associated with reaction free energy $(\mathrm{V}), p_{\mathrm{H} 2}, p_{\mathrm{O} 2}, p_{\mathrm{H} 2 \mathrm{O}}$ are the partial pressures of the component $\left(N / \mathrm{m}^{2}\right), N_{0}$ is the number of cells, $r$ is the electrical resistance of the fuel cell $(\Omega), I^{y}{ }_{f c}$ is the reaction current or the output current $(A), R$ is the universal gas constant $(\mathrm{J} / \mathrm{mol} \mathrm{K}), T$ is the channel temperature $(K), F$ is the Faraday's constant (Coulombs/mol).

The partial pressure of the components is related to its molar flow. The ideal gas law leads to the following relationship:

$$
p_{i} \cdot V_{c h}=n_{i} \cdot R \cdot T
$$

Where, $V_{c h}$ is the volume of the channel $\left(\mathrm{m}^{3}\right)$ and $n_{i}$ is the number of moles of the element $i$ (moles).

The following differential equations describe the chemical behavior of the reactions:

International Journal of Distributed Energy Resources, ISSN 1614-7138, Volume 2 Number 4 (C) 2006 Technology \& Science Publishers, Kassel, Germany, http://www.ts-publishers.com 


$$
\frac{d p_{i}}{d t}=\frac{R \cdot T}{V_{c h}} \frac{d n_{i}}{d t}
$$

and

$$
\frac{d n_{i}}{d t}=q_{i}^{c h}=\left(q_{i}^{i n}-q_{i}^{r}\right)
$$

where, $q_{i}^{i n}$ is the flow of the $i_{t h}$ element of input, $q_{i}^{r}$ is the flow of $i_{t h}$ element that reacts.

For the $\mathrm{H}_{2}$ the value of $q_{i}^{r}$ we have:

$$
q_{H_{2}}^{r}=\frac{N_{0} \cdot I_{f c}^{r}}{2 F}=2 K_{r} I_{f c}^{r}
$$

The values of $q^{r}$ for the other elements are such that:

$$
\begin{aligned}
& q_{0_{2}}^{r}=\frac{q_{H_{2}}^{r}}{2}=K_{r} I_{f c}^{r} \\
& q_{H_{2} 0}^{r}=q_{H_{2}}^{r}=2 K_{r} I_{f c}^{r}
\end{aligned}
$$

Defining the fuel utilization $U_{f}$, as the ratio between the fuel flow that reacts and the input fuel flow and assuming a typical use between 80 and $90 \%$ as described in [14], the demand current of the fuel cell system can be restricted in the range given by:

$$
\frac{0.8 q_{H_{2}}^{i n}}{2 K_{r}} \leq I_{f c}^{r} \leq \frac{0.9 q_{H_{2}}^{i n}}{2 K_{r}}
$$

The optimal utilization factor $\left(\mathrm{U}_{\text {opt }}\right)$ is assumed to be $85 \%$, allowing the control of the input fuel flow by measuring the output current, so that:

$$
q_{H_{2}}^{i n}=\frac{2 K_{r} I_{f c}^{r}}{0.85}
$$

The stichiometric ratio of hydrogen to oxygen is 2 to 1 . Oxygen excess is always taken in, to let hydrogen react with oxygen more completely. According to [14], under normal operation the value of $r_{\mathrm{H} 2 \mathrm{O}}$ should be 1.145 , in order to keep the fuel

International Journal of Distributed Energy Resources, ISSN 1614-7138, Volume 2 Number 4 (c) 2006 Technology \& Science Publishers, Kassel, Germany, http://www.ts-publishers.com 
cell pressure difference below $4 \mathrm{kPa}$. So the input oxygen flow, $q_{\mathrm{O}_{2}}^{\text {in }}$, is controlled to keep $r_{\mathrm{H} 2 \mathrm{O}}$ at 1.145 by controlling the speed of the air compressor.

$$
q_{\mathrm{O}_{2}}^{i n}=r_{\mathrm{H}_{2} \mathrm{O}} \cdot q_{\mathrm{H}_{2}}^{\text {in }}
$$

All the reactions that occur in the fuel cell have some time delay associated. The chemical response in the fuel processor is usually slow, as it is associated with the time to change the chemical reaction parameters after a change in the flow of reactants. This dynamic response function is modeled as a first-order transfer function with a 5 s time delay constant $\left(T_{f}\right)$.

The electrical response time delay in the fuel cells is generally short and mainly associated with the speed at which the chemical reaction is capable of restoring the charge that has been drained by the load. This dynamic response function is also modeled as a first-order transfer function, but with a $0.8 \mathrm{~s}$ time delay constant $\left(T_{e}\right)$. The dynamic response function of the flow is also modeled as a first-order transfer function with the time delay constant of the respective element, $\tau_{\mathrm{H} 2}$, for the response time of hydrogen flow, $\tau_{\mathrm{O} 2}$ for oxygen and $\tau_{\mathrm{H} 2 \mathrm{O}}$ for water flow, as described in [14]. The outputs of this model provide the potential difference between anode and cathode and $I_{f c}^{r}$ the reaction current. A conventional battery can be connected to the $d c$ output of the fuel cell to provide fast response to load step increases.

The interface with the grid is made through an inverter that may include a power frequency control loop for stand alone operation.

\section{E Wind Turbines}

Wind Turbines comprise several subsystems that are modeled independently. These subsystems are the aerodynamic, the generator, the mechanical and the power converters in case of variable speed wind turbines. The models of each subsystem are described next.

1. Aerodynamic subsystem

The aerodynamic coefficient curves are used for the study of the blades dynamics [9]:

$$
P_{a}=\omega_{r} \cdot T_{w}=\frac{1}{2} \cdot \rho \cdot A \cdot C_{p}(\lambda, \beta) \cdot v_{w}^{3}
$$

$P_{\alpha}$ is the aerodynamic power, $C_{p}(\lambda, \beta)$ is the dimensionless performance coefficient, $\lambda$ is the tip speed ratio, $\beta$ is the pitch angle, $\rho$ is the air density, $A=\pi R^{2}$ is the rotor area, $v_{w}$ is the wind speed, $\omega_{r}$ is the blade rotating speed and $T_{w}$ the aerodynamic torque.

In order to reproduce the rotor aerodynamic torque harmonics due to the tower shadow and wind shear effects, each blade must be modeled independently. The

International Journal of Distributed Energy Resources, ISSN 1614-7138, Volume 2 Number 4

(C) 2006 Technology \& Science Publishers, Kassel, Germany, http://www.ts-publishers.com 
tower shadow is approximated by considering a near sinusoidal reduction of the equivalent blade wind speed, as each blade passes in front of the tower.

2. Mechanical subsystem

The equivalents of three or six elastically connected masses can be optionally used for simulating the mechanical system of the WT. The use of at least two masses is necessary for the representation of the low-speed shaft torsional mode. In case of the three-mass equivalent, the state space equations of the model are the following [9], [10]:

$$
\frac{d}{d t}\left[\begin{array}{l}
\theta \\
\omega
\end{array}\right]=\left[\begin{array}{cc}
{[0]_{3 \times 3}} & {[I]_{3 \times 3}} \\
-\frac{1}{2}[H]^{-1}[C] & -\frac{1}{2}[H]^{-1}[D]
\end{array}\right]\left[\begin{array}{c}
\theta \\
\omega
\end{array}\right]+\left[\begin{array}{l}
{[0]_{3 \times 3}} \\
\frac{1}{2}[H]^{-1}
\end{array}\right] T
$$

where $\theta_{T}=\left[\theta_{\mathrm{R}}, \theta_{\mathrm{GB}}, \theta_{\mathrm{G}}\right]$ is the angular position vector, $\omega T=\left[\omega_{\mathrm{R}}, \omega_{\mathrm{GB}}, \omega_{\mathrm{G}}\right]$ is the angular speed vector and $T_{T}=\left[T_{W}, 0, T_{G}\right]$ is the external torque vector comprising the aerodynamic and the electromagnetic torque, $T_{W}$ and $T_{G}[0]_{3 \times 3},[I)_{3 \times 3}$ are the zero and identity $3 \times 3$ matrices, respectively. $[H]=\operatorname{diag}\left(H_{R}, H_{G B}, H_{G}\right)$ is the diagonal inertia matrix, $C$ is the stiffness matrix and $D$ is the damping matrix. $C$ matrix represents the low and high-speed shaft elasticities and is defined by:

$$
[C]=\left[\begin{array}{ccc}
C_{H G B} & -C_{H B G} & 0 \\
-C_{H B G} & C_{H B G}+C_{G B G} & -C_{G B G} \\
0 & -C_{G B G} & C_{G B G}
\end{array}\right]
$$

while,

$$
[D]=\left[\begin{array}{ccc}
D_{R}+d_{H G B} & -d_{H G B} & 0 \\
-d_{H G B} & D_{G B}+d_{H G B}+d_{G B G} & -d_{G B G} \\
0 & -d_{G B G} & D_{G}+d_{G B G}
\end{array}\right]
$$

and represents the internal friction and the torque losses. Subscripts $\{g b\},\{g\}$ denote gear-box and generator, respectively.

\section{F Grid-side inverter}

The circuit diagram of a voltage source controller VSC is shown in and the symbols used are as follows:

$[e]=\left[e_{a} e_{b} e_{c}\right]^{T}$ are the $a c$ source phase voltages, $[i]=\left[i_{a} i_{b} i_{c}\right]^{T}$ are the source currents, $[v]=\left[v_{a} v_{b} v_{c}\right]^{T}$ are the ac side terminal voltages (fundamental component). $R, L$ are the resistance and inductance of ac side series $R-L$ circuit, $C_{d c}$ is the smoothing capacitance and $v_{d c}, i_{d c}$ are the $d c$ side voltage and current, respectively. 
The generic model of a VSC [16] is described next. All model variables are transformed in to the synchronous orthogonal reference frame rotating at the supply frequency using Clarke's transformation.

$[E]=\left[E_{d} E_{q}\right]^{T}$, and $[V]=\left[V_{d} V_{q}\right]^{T}$ are the voltages in $d-q$ reference frame, $[I]=\left[I_{d} I_{q}\right]^{T}$ are the currents in $d-q$ reference frame while $\omega$ is the angular frequency of the ac voltage source. The active power absorbed from the $a c$ source

$$
P_{a c}=3 / 2 \times E_{d} \times I_{d}+3 / 2 \times E_{q} \times I_{q}
$$

Active power delivered to the converter $d c$ side is given by:

$$
\begin{aligned}
& P_{d c}=V_{d c} \times I_{d c}=C_{d c} \times V_{d c} \times \frac{d}{d t} V_{d c}+\frac{1}{R_{d c}} \times V_{d c}^{2} \\
& P_{a c}=P_{d c}+P_{\text {loss }}
\end{aligned}
$$

We can neglect the converter loss without loss of accuracy. Then

$$
C_{d c} \times V_{d c} \frac{d}{d t} V_{d c}+\frac{1}{R_{d c}} \times V_{d c}^{2}=\frac{3}{2} \times E_{d} \times V_{d}+\frac{3}{2} \times E_{q} \times I_{q}
$$

which could be arranged as,

$$
\frac{d}{d t}\left(V_{d c}^{2}\right)=-\frac{2}{R_{d c} \times C_{d c}} \times\left(V_{d c}^{2}\right)+\frac{3 \times E_{d}}{C_{d c}} \times I_{d}+\frac{3 \times E_{q}}{C_{d c}} \times I_{q}
$$

This could also be written as,

$$
\frac{d}{d t}\left(V_{d c}^{2}\right)=k_{d} \times I_{d}+k_{q} \times I_{q}+k_{c} \times\left(V_{d c}^{2}\right)
$$

where,

$$
k_{d}=\frac{3 \times E_{d}}{C_{d c}}, k_{q}=\frac{3 \times E_{q}}{C_{d c}} \text { and } k_{c}=-\frac{2}{R_{d c} \times C_{d c}}
$$

When $V_{d c}^{2}$ is taken as the state variable, instead of $V_{d c}$, this becomes a linear equation. Thus the state-space model including capacitor dynamics could be represented by the following sets of matrices.

International Journal of Distributed Energy Resources, ISSN 1614-7138, Volume 2 Number 4 (C) 2006 Technology \& Science Publishers, Kassel, Germany, http://www.ts-publishers.com 


$$
\begin{aligned}
& \frac{d}{d t}\left[\begin{array}{l}
I_{d} \\
I_{q} \\
\left(V_{d c}^{2}\right.
\end{array}\right]=\left[\begin{array}{ccc}
-R / L & \omega & 0 \\
-\omega & -R / L & 0 \\
k_{d} & k_{q} & k_{c}
\end{array}\right]\left[\begin{array}{c}
I_{d} \\
I_{q} \\
\left(V_{d c}^{2}\right)
\end{array}\right]+\left[\begin{array}{ccc}
1 / L & 0 & 0 \\
0 & 1 / L & 0 \\
0 & 0 & 0
\end{array}\right]\left[\begin{array}{c}
U_{d} \\
U_{q} \\
0
\end{array}\right] \\
& y=\left[\begin{array}{lll}
1 & 0 & 0 \\
0 & 1 & 0 \\
0 & 0 & 1
\end{array}\right]\left[\begin{array}{c}
I_{d} \\
I \\
q \\
\left(\begin{array}{c}
2 \\
d c
\end{array}\right)
\end{array}\right]
\end{aligned}
$$

$I_{d}, I_{q},\left(V_{d c}^{2}\right)$ are the state variables and output variables while $U_{d}, U_{q} U_{d}, U_{q}$ are the input variables of the model.

\section{Control system}

The control system model has two inputs, phase angle and reactive power. Both are fed in by the main system. A three-phase Phase Locked Loop gives out three outputs.

1. Measured frequency in $\mathrm{Hz}$

2. Ramp, $\omega \times t$ which varied between 0 and $2 *$ pi

3. The vector $[\sin (\omega t) \cos (\omega t)]$

The magnitude of $V$ is obtained by regulation of reactive power; $Q$. Using $E$ and $V$, values for $U_{a b c}$ are obtained. ([ $\left.\left.U_{a b c}\right]=\left[E_{a b c}\right]-\left[V_{a b c}\right]\right) . U_{a b c}$ is transformed into $U_{d}$ and $U_{q}$ using Park's transformation to obtain the inputs for the state-space model.

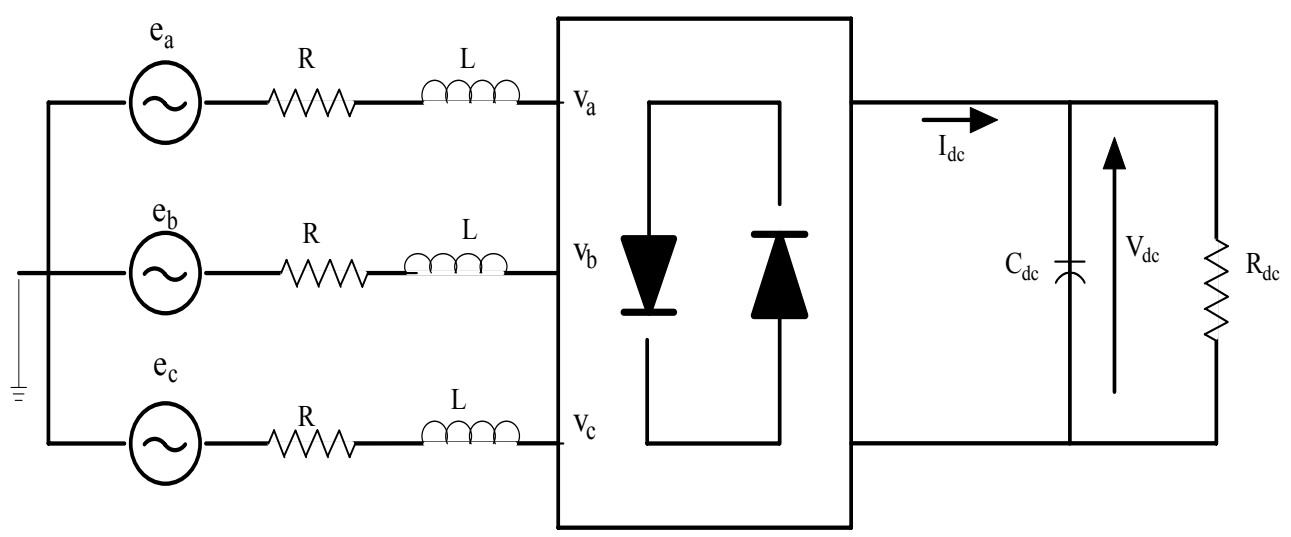

Figure 4: Circuit diagram of three-phase VSC

International Journal of Distributed Energy Resources, ISSN 1614-7138, Volume 2 Number 4 (c) 2006 Technology \& Science Publishers, Kassel, Germany, http://www.ts-publishers.com 


\section{SYSTEM REPRESENTATION AND DYNAMIC ANALYSIS}

The LV network where the MicroGrid will be realized has some features that distinguish it from higher voltage networks. These features consist in that the conductor resistance is higher than the reactance, the unbalanced loading due to singlephase loads and generators and the unbalanced network formation due to the existence of single phase lines.

A distributed neutral conductor usually exists which may be grounded or ungrounded and may be accompanied by a separate earth conductor thus rendering various grounding arrangements designated as TN, TT or IT. Sequence components have long offered a means of analyzing three phase networks and could be used in the network representation.

Nevertheless the benefit of having three decoupled sequence circuits disappears if the network is unbalanced. So it was decided that the network is maintained in its physical configuration having any number of phase, neutral or grounding conductors as it is required.

A typical building component of the network, which may correspond to a line or a cable comprising three phases and a neutral conductor is illustrated in Figure 5.

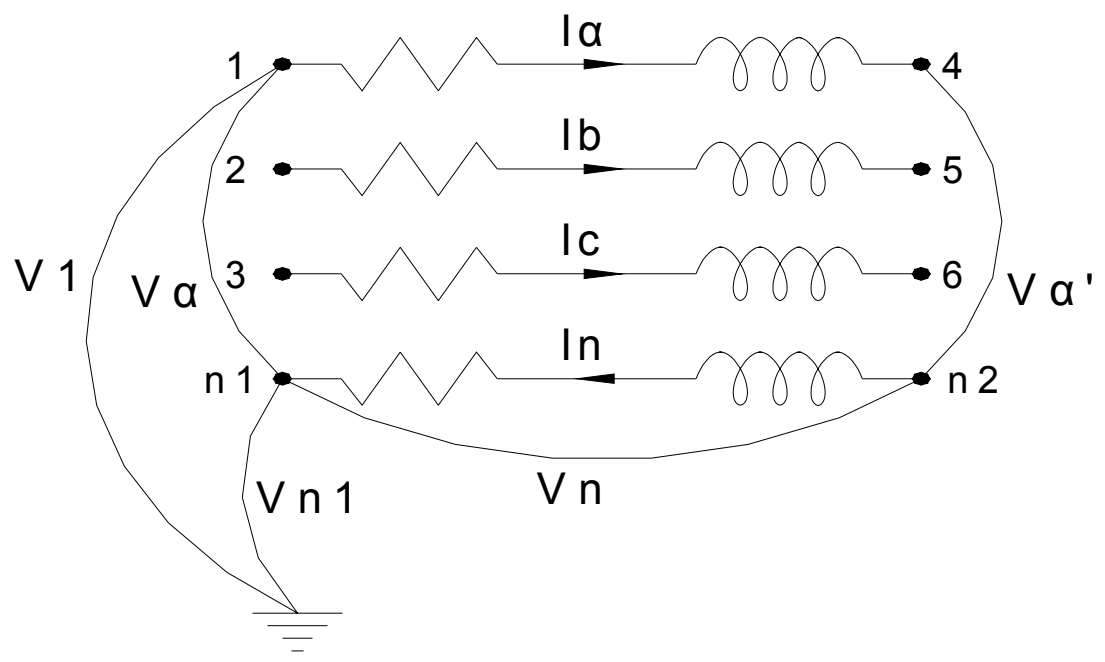

Figure 5: $\quad$ Example microgrid, LV feeder integrating microsources

Writing Kirchhoff's voltage equations for phase $\alpha$ we have:

$$
-V_{a}+V_{a^{\prime}}+I_{a} Z_{a a}+I_{b} Z_{a b}+I_{c} Z_{a c}-I_{n} Z_{a n}+V_{n}=0
$$

Expressing the voltages to neutral of the two terminals properly and taking into account that $V_{n}=\left(I_{a}+I_{b}+I_{c}\right) Z_{n}$ the mesh equation for phase $\alpha$ omitting the mutual coupling for simplicity will be [3]-[5]:

International Journal of Distributed Energy Resources, ISSN 1614-7138, Volume 2 Number 4 (C) 2006 Technology \& Science Publishers, Kassel, Germany, http://www.ts-publishers.com 


$$
\left(V_{1}-V_{n 1}\right)-\left(V_{4}-V_{n 2}\right)=I_{a}\left(Z_{a a}+Z_{n}\right)+I_{b} Z_{n}+I_{c} Z_{n}
$$

Following the same for the other two phases and inverting we arrive at the primitive equations in admittance form with the presence of the neutral conductor incorporated, which relate the phase branch currents with the phase branch voltages:

$$
\left[\begin{array}{c}
I_{a} \\
I_{b} \\
I_{c}
\end{array}\right]=Y_{a b c(n)}\left[\begin{array}{l}
V_{1-n 1}-V_{4-n 2} \\
V_{2-n 1}-V_{5-n 2} \\
V_{3-n 1}-V_{6-n 2}
\end{array}\right]
$$

$Y_{a b c(n)}$ is the primitive admittance matrix and the letter $n$ in the parenthesis implies that the neutral conductor is incorporated, whereas the subscripts in the voltages declare the nodes at which the potential differences are measured.

Writing current injections as a function of branch currents and branch voltages as a function of node voltages [3]-[5]:

$$
\begin{aligned}
& {\left[\begin{array}{c}
I_{1 n 1} \\
I_{2 n 1} \\
I_{3 n 1} \\
I_{4 n 2} \\
I_{5 n 2} \\
I_{6 n 2}
\end{array}\right]=\left[\begin{array}{ccc}
1 & & \\
& 1 & \\
& & 1 \\
-1 & & \\
& -1 & \\
& & -1
\end{array}\right]\left[\begin{array}{l}
I_{a} \\
I_{b} \\
I_{c}
\end{array}\right]=A I_{a b c}} \\
& {\left[\begin{array}{l}
V_{1-n 1}-V_{4-n 2} \\
V_{2-n 1}-V_{5-n 2} \\
V_{3-n 1}-V_{6-n 2}
\end{array}\right]=A^{T}\left[\begin{array}{l}
V_{1-n 1} \\
V_{2-n 1} \\
V_{3-n 1} \\
V_{4-n 2} \\
V_{5-n 2} \\
V_{6-n 2}
\end{array}\right]}
\end{aligned}
$$

Combining (34), (33) with (32) we obtain the nodal equations of the line or cable component: 


$$
\left[\begin{array}{c}
I_{1 n 1} \\
I_{2 n 1} \\
I_{3 n 1} \\
I_{4 n 2} \\
I_{5 n 2} \\
I_{6 n 2}
\end{array}\right]=A Y_{a b c(n)} A^{T}\left[\begin{array}{l}
V_{1-n 1}-V_{4-n 2} \\
V_{2-n 1}-V_{5-n 2} \\
V_{3-n 1}-V_{6-n 2}
\end{array}\right]
$$

If matrix $A$, which is the connection or incidence matrix, is written as two $3 \times 3$ identity matrices $A^{T}$ ) $[I-I]$, then the nodal equations can be written:

$$
\left[\begin{array}{c}
I_{1,2,3} \\
I_{4,5,6}
\end{array}\right]=\left[\begin{array}{cc}
Y_{a b c(n)} & -Y_{a b c(n)} \\
-Y_{a b c(n)} & Y_{a b c(n)}
\end{array}\right]\left[\begin{array}{c}
V_{1,2,3} \\
V_{4,5,6}
\end{array}\right]
$$

where the four conductor line or cable can be considered as a single component having a compound branch admittance $Y_{a b c(n)}$. Utilizing the idea of representing each four wire conductor with the above compound branch admittance matrix and the network incidence matrix with elements of identity matrices of $3 \times 3$ dimension the nodal admittance matrix of any network configuration can be built by inspection [3]-[5]. The procedure is the same as for a network represented with single admittance components if we treat the compound branch admittances accordingly. A Y-connected constant impedance load will have a compound admittance in the following form.

$$
\left[\begin{array}{lll}
\left(P_{a}-i Q_{a}\right) /\left|V_{a}\right|^{2} & & \\
& \left(P_{b}-i Q_{b}\right) /\left|V_{b}\right|^{2} & \\
& & \left(P_{c}-i Q_{c}\right) /\left|V_{c}\right|^{2}
\end{array}\right]
$$

This is directly included in the network admittance matrix at the nodes that are the load terminals.

The modelling of the MV/LV transformer follows a similar procedure be [3]-[5]. In this case the incidence matrix $A$ depicts how the mutually coupled branches are connected following the actual connection of the transformer windings.

To facilitate the dynamic analysis of extended systems the approach of stability algorithms is employed. Therefore, the solution of the sources is performed in the time domain with differential equations and a steady state frequency domain solution is used for the network as it was implied so far in the network modelling. In this way the network components are represented as constant frequency imped-

International Journal of Distributed Energy Resources, ISSN 1614-7138, Volume 2 Number 4 (C) 2006 Technology \& Science Publishers, Kassel, Germany, http://www.ts-publishers.com 
ances and voltages, currents in a phasor form are used to solve the network algebraic equations in conjunction with the time domain solution of the sources [6], [7].

Due to the fact that the terminal voltages and currents at the sources terminals are instantaneous values obtained from the time domain solution at discrete time points while phasors are required for the network solution, the following principles are adopted for their proper interface.

Source stator transients are neglected and stator impedances become part of the network, while all sources are seen from the network as emfs behind an impedance, e.g. transient emf behind the transient impedance for rotating machines. The magnitude and angle of this emf will be provided to the network as an output from the differential equations solution of the source at every time step. In particular, for $3 \mathrm{ph}$ or $1 \mathrm{ph}$ Voltage source inverters the magnitude and phase angle required are the magnitude and phase angle of phase $\alpha, E_{a} \angle \theta_{e}(t)$ where the phase angle $\theta_{e}(t)$ is:

$$
e_{a}=\sqrt{2} E_{a} \cos \left(\int_{0}^{t} \omega_{e}(t) d t+\theta_{0}\right)=\sqrt{2} E_{a} \cos \theta_{e}(t)
$$

This is the same as providing $E_{d}, E_{q}$ in the stationary frame which has $d$ axis aligned with the $\alpha$ phase axis, as it is also the case for the rotating machines coupled directly to the network.

The solution of the network algebraic equations returns back to the source the stator positive sequence current $I_{l}$ to be used for the integration of the next time step as well as any other value that may be needed for control purposes such as the stator terminal voltage.

It is assumed as it becomes obvious from the above that the internal emfs produced by the sources are balanced (of positive sequence only). So the time domain solution of the sources takes place only for the positive sequence values. In the negative sequence the source is assumed to react only with its negative sequence impedance and this is accounted for including the stator impedance in the network admittance matrix.

It is noted that the principles stated above are applicable for the examination of the dynamic behaviour of the MicroGrid both when it is connected to the distribution system and when it operates autonomously.

Figure 5 depicts a LV study case network, which was used to test the performance of the simulation tool.

Various disturbances were examined using the developed simulation tool such as:

- Isolation from the main grid.

- Step changes of the load in the MicroGrid.

- Variations of the production of dispersed generators

International Journal of Distributed Energy Resources, ISSN 1614-7138, Volume 2 Number 4 (c) 2006 Technology \& Science Publishers, Kassel, Germany, http://www.ts-publishers.com 
- Loss of grid forming units (battery inverters).

Selected graphs from the results obtained are presented in the following figures. $P$ and $Q$ are plotted with continuous and hidden lines respectively and with a load convention.

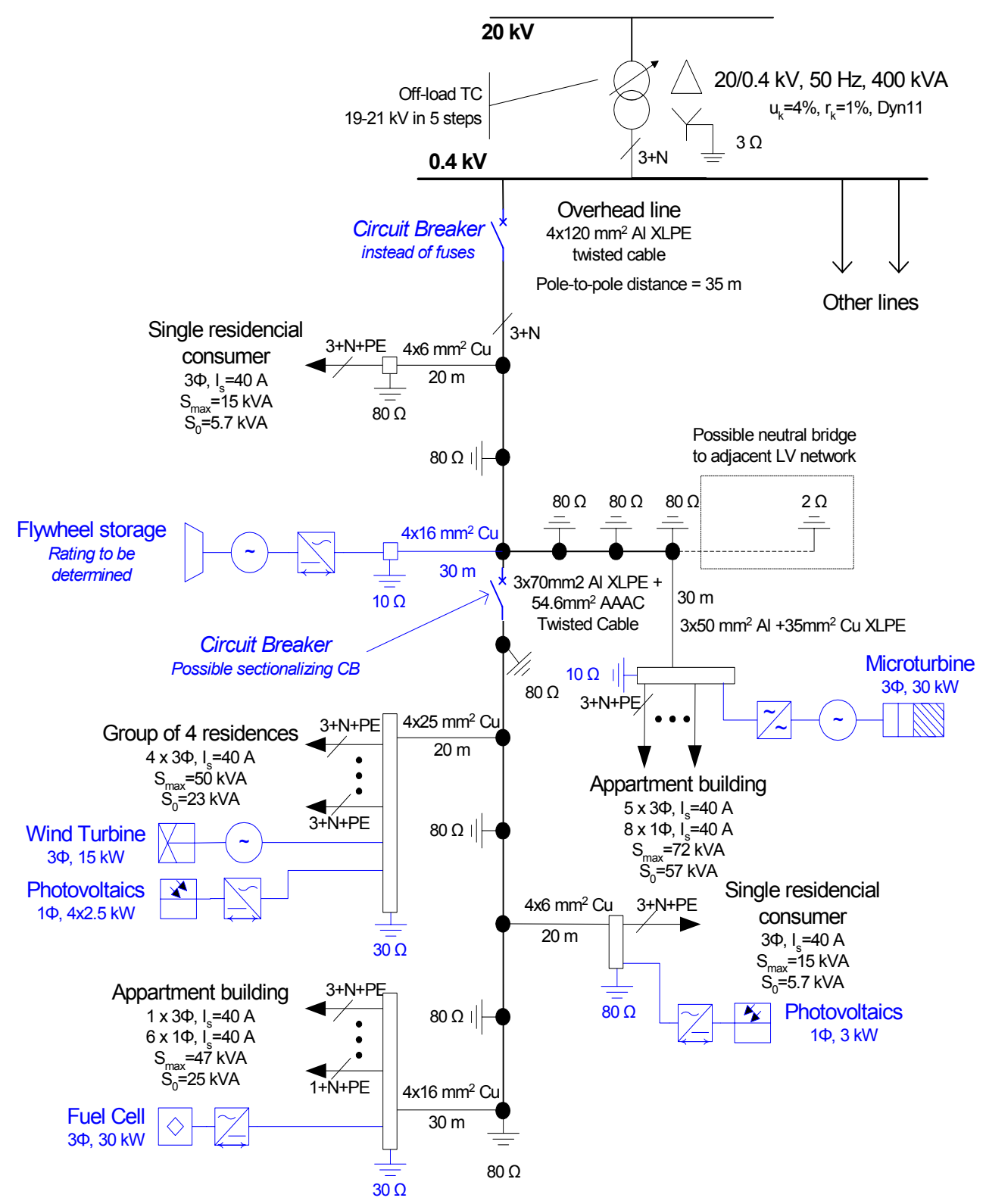

Figure 6: $\quad$ Study case LV MicrGrid system proposed in the frame of [1]

International Journal of Distributed Energy Resources, ISSN 1614-7138, Volume 2 Number 4 (C) 2006 Technology \& Science Publishers, Kassel, Germany, http://www.ts-publishers.com 

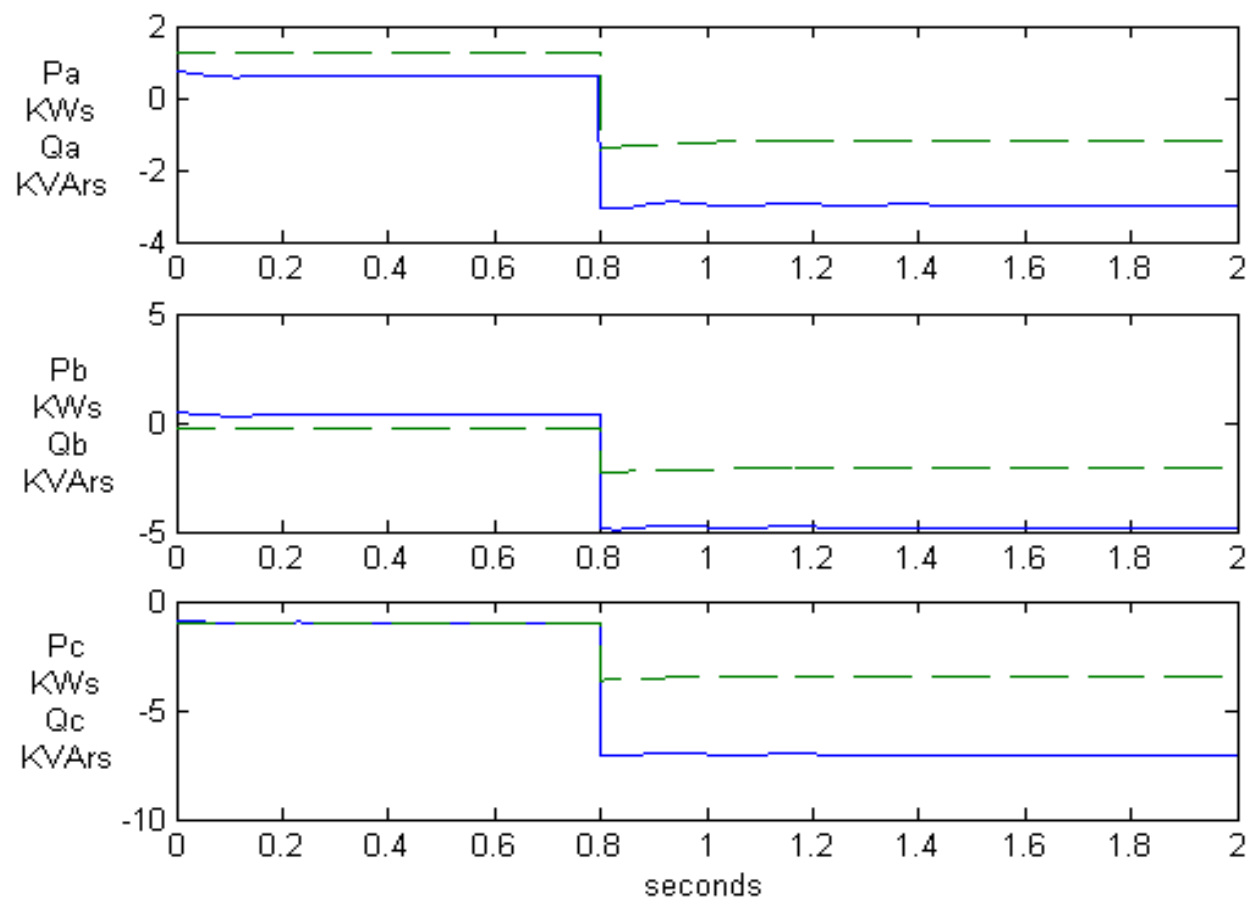

Figure 7: Change of the production of a battery inverter upon grid disconnection at $0.8 \mathrm{sec}$
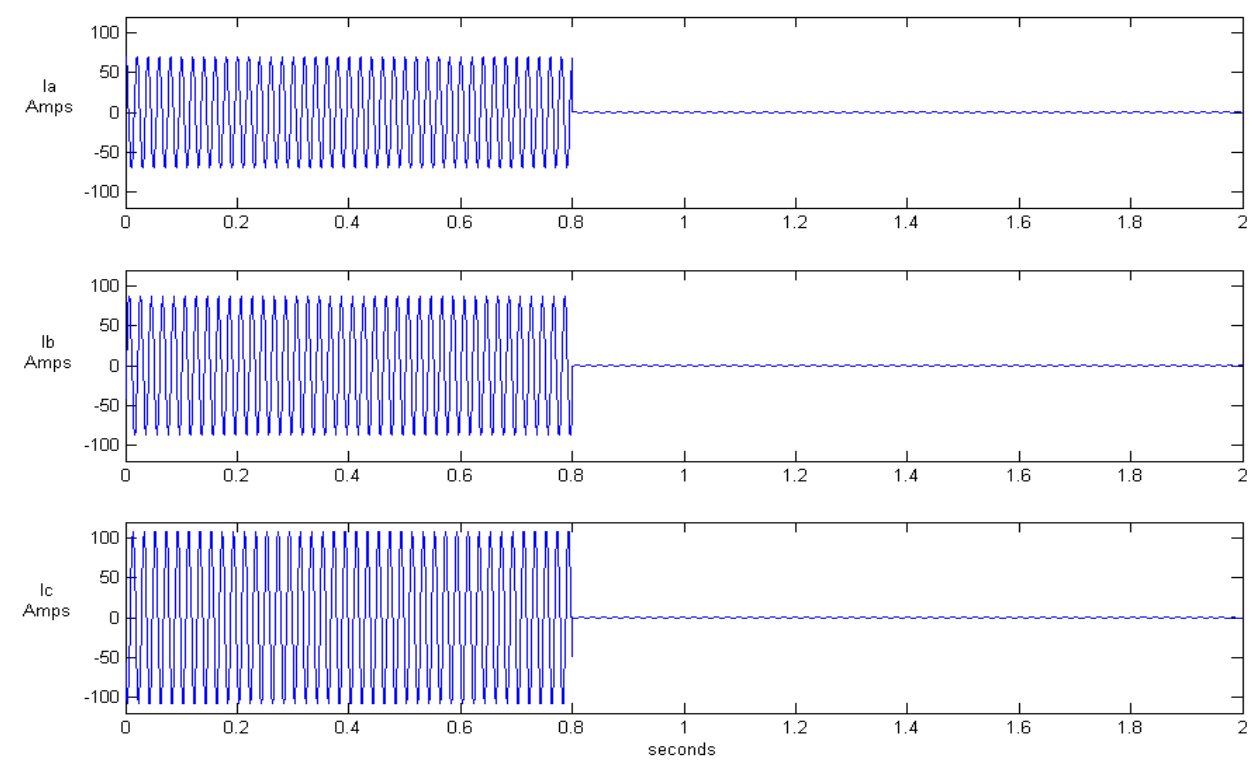

Figure 8: Currents of the grid supply cable. Grid disconnection at $0.8 \mathrm{sec}$

International Journal of Distributed Energy Resources, ISSN 1614-7138, Volume 2 Number 4 (c) 2006 Technology \& Science Publishers, Kassel, Germany, http://www.ts-publishers.com 

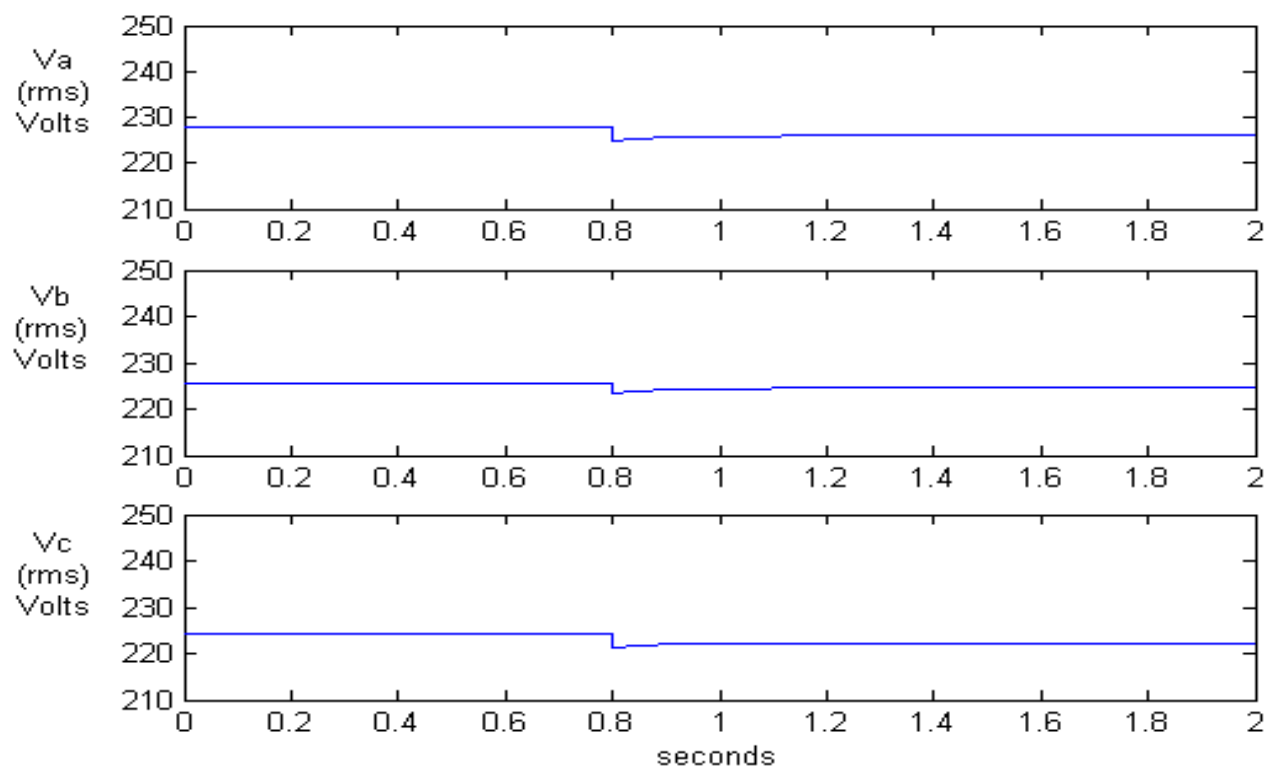

Figure 9: $\quad$ Phase voltages at a load node. Grid disconnection at $0.8 \mathrm{sec}$

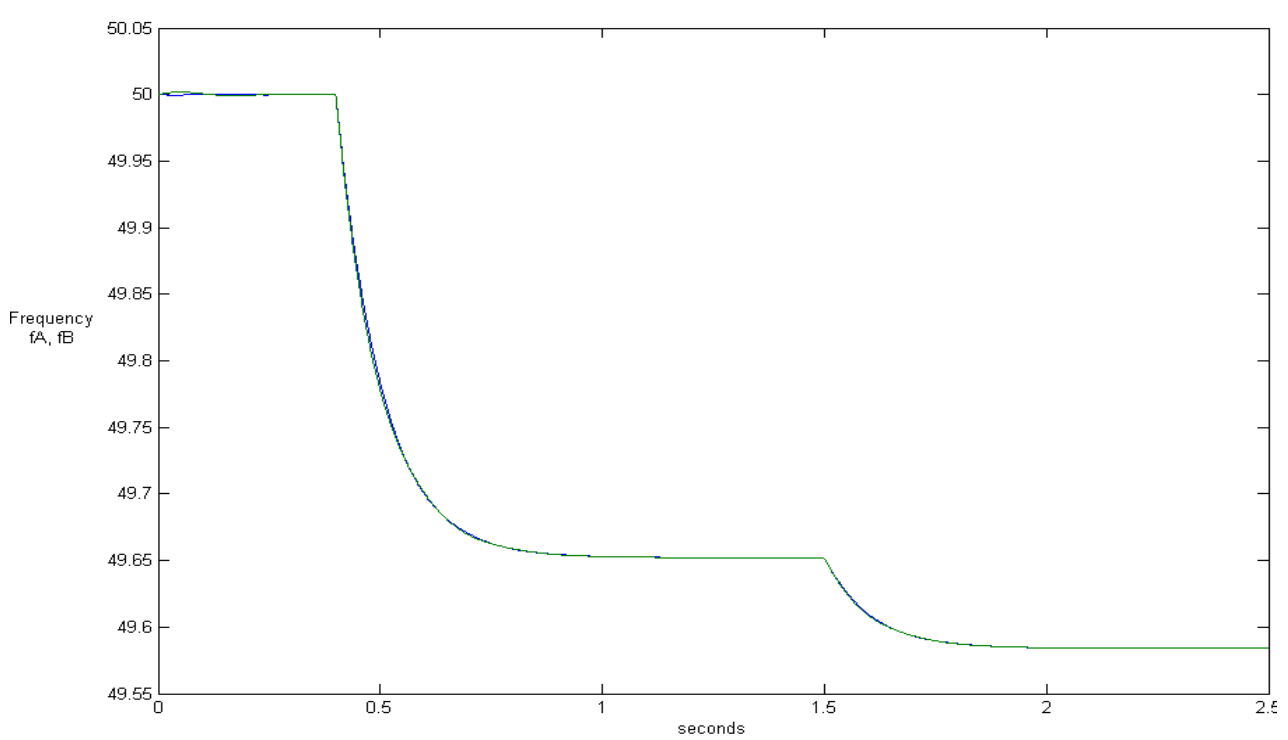

Figure 10: System frequency when MicroGrid is isolated at $0.5 \mathrm{sec}$ and the system load increases by $25 \%$ at $1.5 \mathrm{sec}$

International Journal of Distributed Energy Resources, ISSN 1614-7138, Volume 2 Number 4 (c) 2006 Technology \& Science Publishers, Kassel, Germany, http://www.ts-publishers.com 

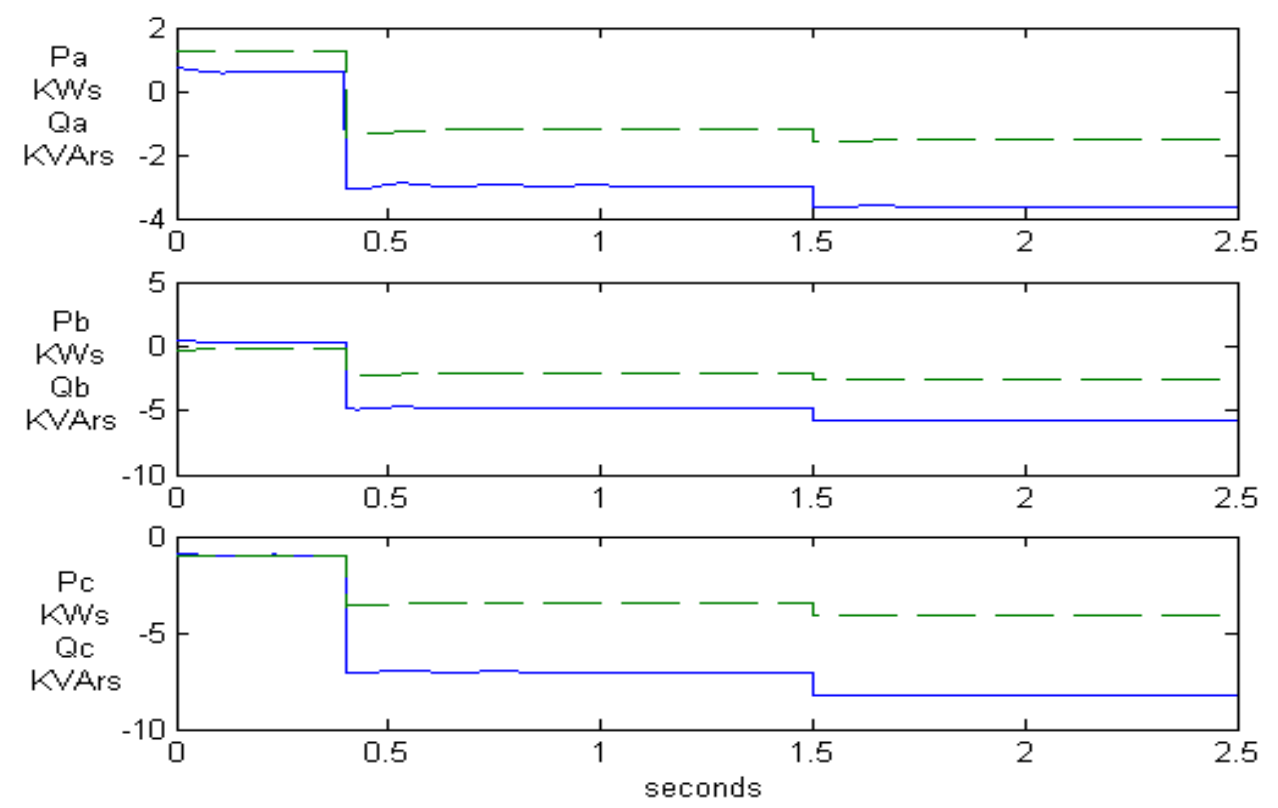

Figure 11: Production of a battery inverter when the MicroGrid is isolated at $0.5 \mathrm{sec}$ and the system load increases by $25 \%$ at $1.5 \mathrm{sec}$
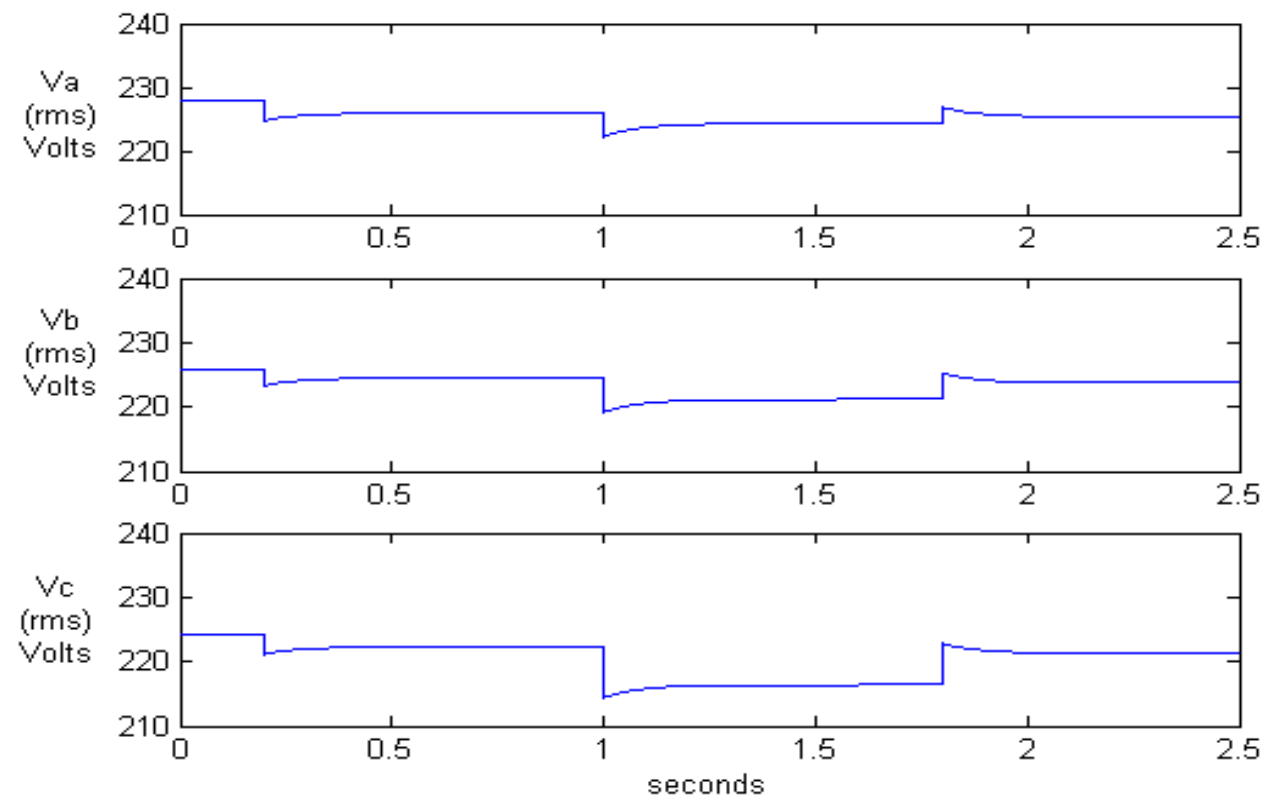

Figure 12: Load phase voltages. Grid disconnection at 0.2sec, loss of a battery inverter at $1 \mathrm{sec}$ followed by shedding of the $50 \%$ of the system load 


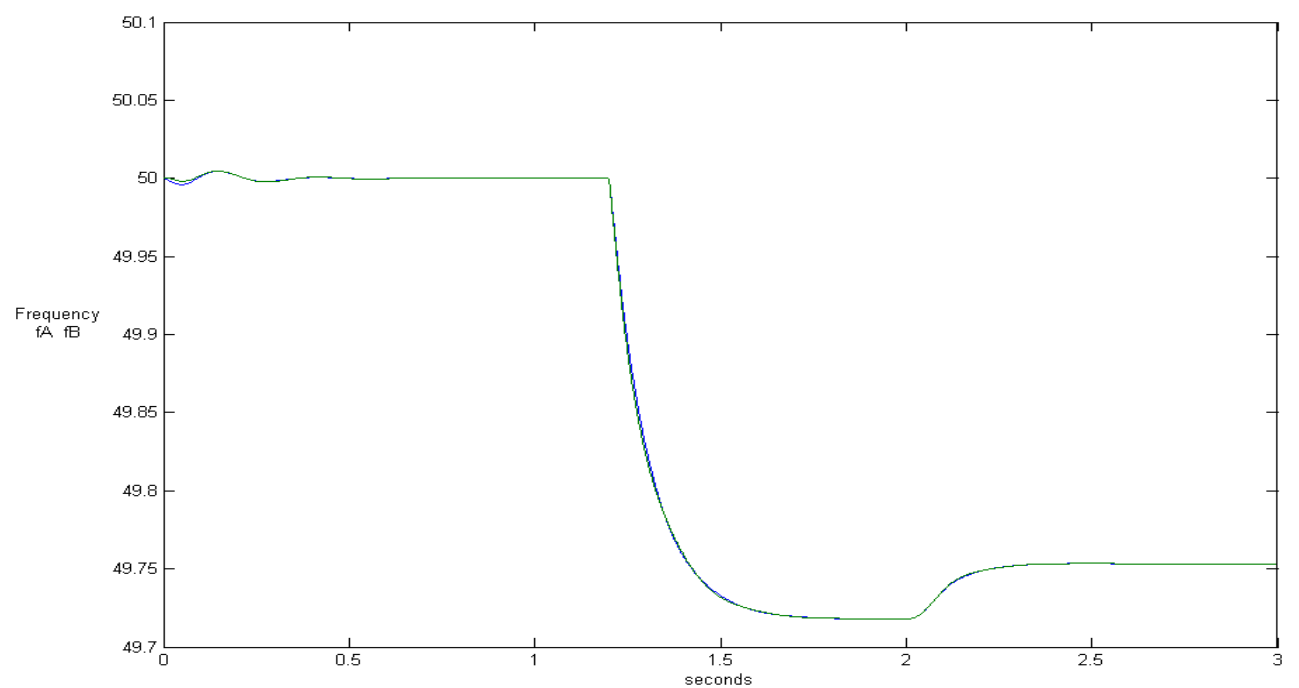

Figure 13: System frequency when grid disconnection occurs at 1.2sec and the production of the $P V$ units increases at $2 \mathrm{sec}$

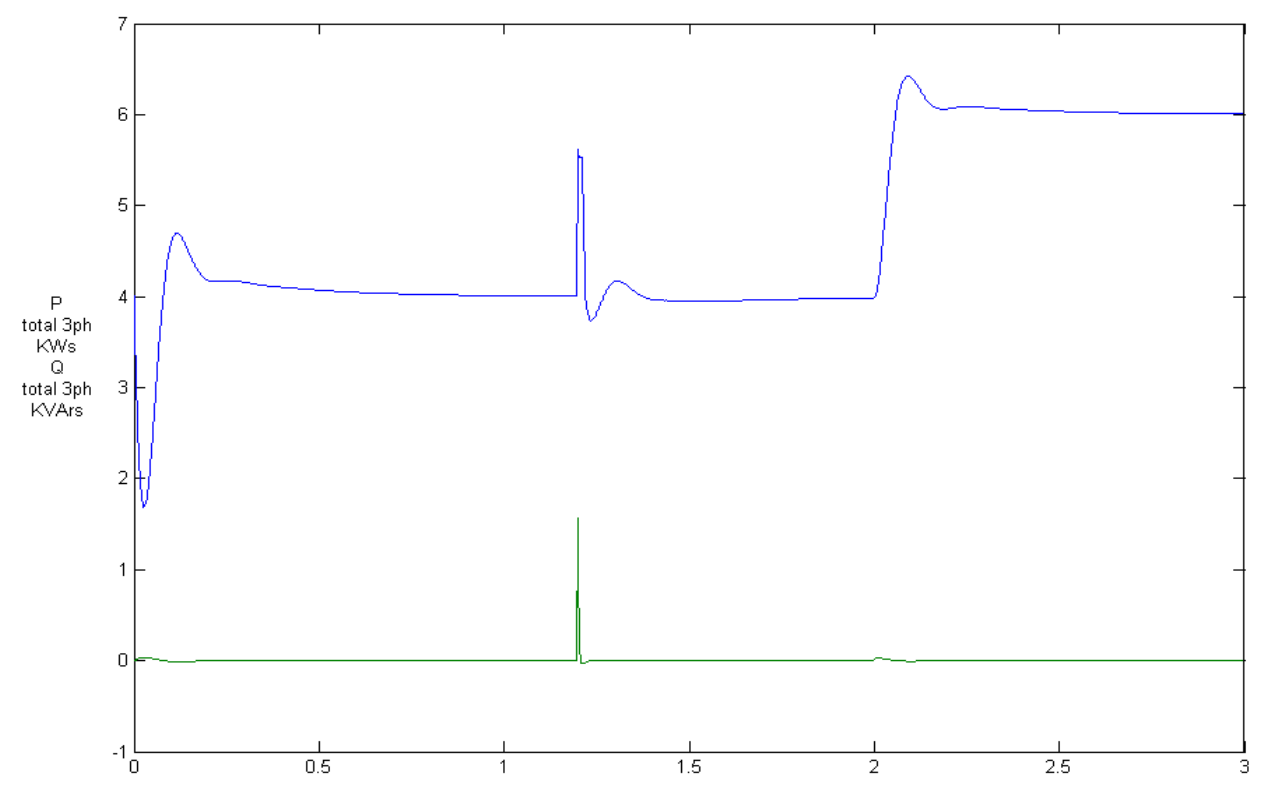

Figure 14: Production of a PV unit. Grid is disconnected at $1.2 \mathrm{sec}$ and the production of the $P V$ unit increases at $2 \mathrm{sec}$

International Journal of Distributed Energy Resources, ISSN 1614-7138, Volume 2 Number 4 (c) 2006 Technology \& Science Publishers, Kassel, Germany, http://www.ts-publishers.com 

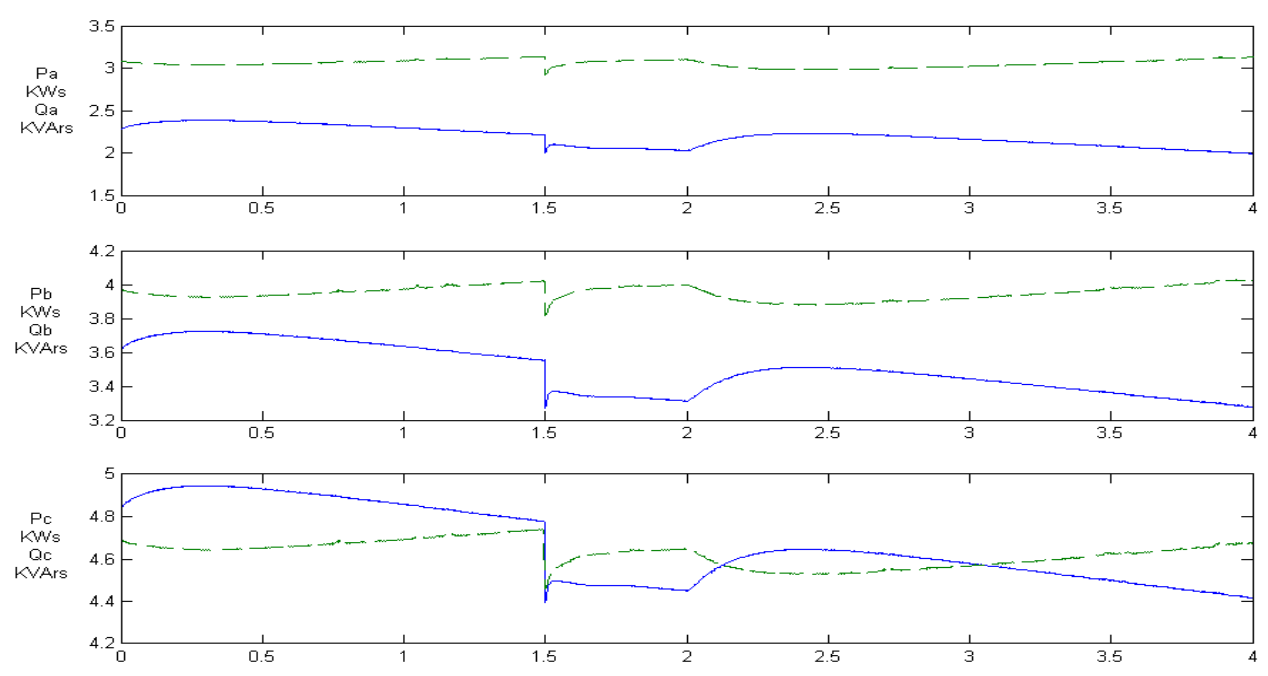

Figure 15: Load consumption from the network at the node where the wind turbine is connected. Grid is disconnected at $1.5 \mathrm{sec}$

\section{CONCLUSIONS}

A simulation tool developed for the dynamic analysis of the MicroGrid is described and applied to selected studies cases, in order to demonstrate its capability to analyze LV microgrids of realistic size and complexity.

The simulation tool has been built around a network solver code, developed in Matlab, which is capable of solving balanced and unbalanced networks in steady state and dynamic conditions. An important characteristic of the solver is its open architecture that permits interfacing of practically any source or load model. The simulation code has been tested in various network conditions and disturbances and its adequacy is verified by the study cases included in this report.

All simulations concern a LV study case grid, with various combinations of sources connected to its nodes. Disturbances considered include sudden isolation from the main grid, load changes, loss of grid forming units (battery inverters) and changes in the production level of "non-dispatchable" sources. In all cases, the simulation results are absolutely reasonable and expected, confirming the suitability of the code for the dynamic analysis of MicroGrids.

\section{ACKNOWLEDGEMENT}

The authors wish to thank the EC for funding the "MICROGRIDS-Large Scale Integration of Micro-Generation to Low Voltage Grids", Project, EU Contract ENK5-CT-2002-00610. 


\section{REFERENCES}

[1] MICROGRIDS - Large Scale Integration of Micro-Generation to Low Voltage Grids. EU Contract ENK5-CT-2002-00610, http://microgrids.power. ece.ntua.gr.

[2] R. Lasseter at al: The CERTS Microgrid Concept. White paper on Integration of Distributed Energy Resources, April 2002.

[3] M. S. Chen, W. E. Dillon: Power system modeling. Proc. IEEE, 62 (7) 901, July 1974.

[4] J. Arrillaga, C. P. Arnold: Computer modeling of electrical power systems. J. Wiley \& Sons, 1983.

[5] M. A. Laughton: Analysis of unbalanced polyphase networks by the method of phase coordinates. Part I System representation in phase frame of reference. Proc. IEE, 115 (8), 1163-1172, Aug. 1968.

[6] S. M. Halpin, L. L. Grigsby, C. A. Gross, R. M. Nelms: An Improved method for including detailed synchronous machine representations in large power system models for fault analysis. IEEE Trans. Energy Conversion, Vol. 8, No 4, December 1993, pp 719-725.

[7] Halpin S. M., Grigsby L. L., Gross C. A., Nelms R. M.: An Improved fault analysis algorithm for unbalanced multi-machine power distribution systems. IEEE Trans. Power Delivery, Vol 9, No 3, July 1994, pp 1332-1338.

[8] Hatziargyriou, N., Kariniotakis, et al:Modelling of microsources for security studies. CD-Rom Proceedings of the 2004 CIGRE SESSION, Paris, France. 29 August-3 September 2004.

[9] Modelling New Forms of Generation and Storage. Technical Brochure CIGRE Task Force 38.01.10, Nov. 2000.

[10] F. D. Kanellos, N.D. Hatziargyriou: The Effect of Variable Speed Wind Turbines on the Operation of Weak Distribution Networks. IEEE Trans. on Energy Conversion, vol: 17, issue: 4, pages: 543 -548, December 2002.

[11] J.H. Watts: Microturbines: a new class of gas turbine engines. Gas Turbine News in Brief 39 (1), 5-11, 1999.

[12] P. M. Anderson, A. A. Fouad: Power System Control \& Stability. Iowa: The Iowa State University Press, 1977.

[13] M. Nagpal, A. Moshref, G.K. Morison, et al.: Experience with testing and modelling of gas turbines. Proc. of the IEEE/PES 2001 Winter Meeting, pp. 652-656, Jan./Feb. 2001, Columbus, Ohio, USA.

[14] Y. Zhu, K. Tomsovic: Development of models for analysing load-following performance of microturbines and fuel cells. Electric Power Systems Research 62, 1-11, 2002.

International Journal of Distributed Energy Resources, ISSN 1614-7138, Volume 2 Number 4

(C) 2006 Technology \& Science Publishers, Kassel, Germany, http://www.ts-publishers.com 
[15] F. D. Kanellos, N.D. Hatziargyriou: The Effect of Variable Speed Wind Turbines on the Operation of Weak Distribution Networks. IEEE Trans. on Energy Conversion, vol: 17, issue: 4, pages: 543 -548, December 2002.

[16] Schauder, C., Mehta, H.: Vector Analysis and Control of Advanced Static VAR compensators. IEE PROCEEDINGS-C, Vol. 140, No.4, July 1993.

[17] Kariniotakis, G. N. et. al: Dynamic Modelling of MicroGrids. Intern. Conference on Future Power Systems, Nov. 2005, ISBN 90-78205-01-6

\section{BIOGRAPHIES}

George N. Kariniotakis was born in Athens, Greece. He received the Diploma in Production and Management Engineering from the Technical University of Crete, Greece in 1990 and the Ph.D. degree in Energetics in 1996 from Ecole Nationale Supérieure des Mines de Paris, France. At present he is Scientific Manager at the Centre for Energy and Processes of Ecole des Mines de Paris. His research interests include wind energy, distributed generation, timeseries forecasting, and application of AI and optimisation techniques to power systems. Currently he is the scientific coordinator of the Anemos project on wind power forecasting (http://anemos.cma.fr). He is member of IEEE and the Technical Chamber of Greece.

Nikos L. Soultanis received Diploma in Electrical Engineering from NTUA in 1989 and M.Sc. from UMIST Manchester, UK in 2000. Presently he is a PhD student in NTUA. His research interests are dispersed generation and power system analysis. He is a member of the IEE and of the Technical Chamber of Greece.

A. I. Tsouchnikas received his Electrical and Computer Engineering degree at National Technical University of Athens (NTUA), in 2004. Currently he is a PhD student in the Electrical Engineering Department of NTUA. His research interests include renewable energy sources and dispersed generation.

Stavros A. Papathanasiou (S'1993, M'1998) received the Diploma in Electrical Engineering in 1991 and the Ph.D. degree in 1997 from the National Technical University of Athens (NTUA), Greece. He worked for the Distribution Division of the Public Power Corporation of Greece, in power quality and distributed generation studies. In 2002 he joined the Electric Power Division of NTUA as a lecturer. His research mainly deals with wind turbine technology and the integration of distributed generation in distribution networks. He is a member of the IEEE, CIGRE and a registered professional engineer and member of the Technical Chamber of Greece.

Nikos D. Hatziargyriou was born in Athens, Greece. He received the Diploma in Electrical and Mechanical Engineering from NTUA and MSc and PhD degrees from UMIST, Manchester, UK. He is professor at the Power Division of the Electrical and Computer Engineering Department of NTUA. His research interests include Dispersed and Renewable Generation, Dynamic Security Assessment, and application of Artificial Intelligence Techniques to power systems. He is senior IEEE member, member of CIGRE SCC6 and the Technical Chamber of Greece.

J. A. Peças Lopes is an Associate Professor with Aggregation in the Dept. of EE of the Faculty of Engineering of University of Porto. He obtained an Electrical Engineering degree (5 years course) in 1981 from University of Porto and a PhD. degree also in Electrical Engineering from the same University in 1988. In 1996 he got an Aggregation degree. In 1989 he joined the staff of INESC as a senior researcher and he is presently Adjoint Coordinator of the Power Systems Unit of INESC Porto and a senior member of the IEEE.

Nilanga Jayawarna, received her BSc. in Electrical Engineering from the University of Moratuwa, Sri Lanka in 2001. At present she is reading for her PhD at the University of Manchester, UK. Her main research area is safety and protection of MicroGrids.

International Journal of Distributed Energy Resources, ISSN 1614-7138, Volume 2 Number 4 (c) 2006 Technology \& Science Publishers, Kassel, Germany, http://www.ts-publishers.com 
Nicholas Jenkins received the B.Sc. Degree from Southampton University, U.K., the M.Sc. degree from Reading University, U.K., and the Ph.D. degree from Imperial College London, U.K., in 1974, 1975, and 1986, respectively. His industrial experience includes periods with Eastern Electricity, U.K., Ewbank Preece Consulting Engineering, U.K., and BP Solar and Wind Energy Group, U.K. He joined the University of Manchester in 1992 where he is now a Professor.

International Journal of Distributed Energy Resources, ISSN 1614-7138, Volume 2 Number 4 (c) 2006 Technology \& Science Publishers, Kassel, Germany, http://www.ts-publishers.com 
